\title{
Anticancer potential of Salvia miltiorrhiza and its tanshinones: an efficacy perspective
}

This article was published in the following Dove Press journal:

Botanics: Targets and Therapy

29 April 2016

Number of times this article has been viewed

\author{
Wei Wu' \\ Yong Zhang \\ Suni Tang' \\ Min $\mathrm{Ye}^{2}$ \\ Junxuan Lü' \\ Cheng Jiang' \\ 'Department of Biomedical Sciences, \\ Texas Tech University Health Sciences \\ Center School of Pharmacy, Amarillo, \\ TX, USA; ${ }^{2}$ State Key Laboratory of \\ Natural and Biomimetic Drugs, School \\ of Pharmaceutical Sciences, Peking \\ University, Beijing, People's Republic \\ of China
}

\begin{abstract}
Salvia miltiorrhiza Bunge (Danshen in Chinese or Tanshen in Anglicized literature) is a well-known Traditional Chinese Medicine herbal remedy for treating cardiovascular- and cerebrovascular-related disorders. To date, $>40$ hydrophorbic tanshinones and structurally related compounds have been isolated from the Danshen root, as have some 50 hydrophilic phenolics and other minor components. In the past 2 decades, a large quantity of literature has reported inhibitory activities of tanshinones against cancers of various organ sites in cell culture models, and in some cases with efficacy confirmation in preclinical animal cancer models. This study follows up on a 2012 review we published on the sources, pharmacokinetics, and anticancer activities of tanshinones. Here, we update on the recent progress in understanding the anticancer potential of tanshinones and derivatives and critically assess merits of these entities for future research and development. Overall, potency data from in vivo efficacy assessment experiments in preclinical models varied from nil for chemoprevention of a prostate carcinogenesis model to strong inhibition of some xenograft or allograft models. Lack of uniformity of excipients, doses, and routes of administration aside, we caution that the reviewed data should be appreciated in balance of publication bias exemplified by our own data from primary carcinogenesis study and false positivity. Novel formulations and chemical modifications had been made to improve the poor solubility and bioavailability of tanshinones. Human clinical studies so far dealt with case reports of tanshinone IIA use and small-scale trials on Danshen-containing formulas with chemotherapy for cancers of multiple organ sites in People's Republic of China. Available human data are not sufficient for supporting any anticancer indication of tanshinones.
\end{abstract}

Keywords: human studies, cancer therapy, cancer chemoprevention, preclinical efficacy

\section{Introduction}

The dried roots of Danshen (in Chinese) or Tanshen (in Anglicized literature) Salvia miltiorrhiza Bunge have been used in Traditional Chinese Medicine (TCM) in People's Republic of China and Asian countries as preventive or therapeutic remedies for coronary heart diseases, vascular diseases, stroke, hyperlipidemia, endangiitis, arthritis, and hepatitis. ${ }^{1,2}$ Fufang Danshen, a composite multi-herbal TCM formula containing Danshen as the major ingredient, has been officially listed in the Chinese Pharmacopeia for many indications. Recently, Danshen has been recorded as a monograph in United States Pharmacopeia USP 37/NF 32 ed.; 2014). In the USA, a Phase II clinical trial has been completed with Fufang Danshen Dripping Pills (best-known commercialized forms of mixture of Danshen, Radix notoginseng [San Qi in Chinese] and borneolum [Bing Pian in Chinese]) for evaluating the efficacy and safety in patients with chronic stable angina pectoris (Clinicaltrials.gov NCT00797953). A large-scale Phase III trial
Correspondence: Cheng Jiang; Junxuan Liu Department of Pharmacology, Penn State Hershey College of Medicine, PO Box 850, MC RI30, Hershey, PA I7033, USA

Tel +I 7175318964

Email cjiang@hmc.psu.edu; junxuanlu@ hmc.psu.edu
Botanics:Targets and Therapy 2016:6 45-58

Dovepress

http://dx.doi.org/10.2147/BTAT.S68097 (c) (i) (5) ๑ 2016 Wu et al. This work is published and licensed by Dove Medical Press Limited. The full terms of this license are available at https://www.dovepress.com/terms.php (c)
hereby accept the Terms. Non-commercial uses of the work are permitted without any further permission from Dove Medical Press Limited, provided the work is properly attributed. For permission for commercial use of this work, please see paragraphs 4.2 and 5 of our Terms (https://www.dovepress.com/terms.php). 
with the Dripping Pills (NCT01659580) is being conducted in the USA, Canada, Mexico, and several European countries for the same indication. Three Phase I trials (NCT01473888, NCT01475279, NCT01679028) have been completed to study safety, interaction with P450, or Warfarin use.

To date, $>90$ chemicals have been identified from Danshen. They belong to two major groups: $>40$ hydrophobic ${ }^{2,3}$ and $>50$ hydrophilic compounds. ${ }^{1}$ Tanshinones are hydrophobic abietane diterpenes. First isolated and named in the 1930s by Nakao and Fukushima, ${ }^{4}$ they now include (Figure 1A) cryptotanshinone (CT, 1), tanshinone IIA (TIIA, 2), tanshinone IIB (TIIB, 3), tanshinone I (TI, 4), dihydrotanshinone I (DH-TI, 5), tanshindiols B and C (6, 7), methyltanshinone (8), isotanshinone I, isocryptotanshinone I, and isocryptotanshinone II. ${ }^{1,3,5-9}$ Tanshinlactone (9) and neo-tanshinlactone (10) are structurally related to tanshinone backbone and have been reported to possess anticancer activities as well. ${ }^{2}$

The hydrophilic chemicals isolated from Danshen include danshensu (also known as salvianic acid A or salvianic acid B), protocatechuic acid, protocatechuic aldehyde, rosmarinic acid, and salvianolic acids $\mathrm{A}, \mathrm{B}$, and $\mathrm{C}$, with the last three also known as lithospermic acids $\mathrm{A}-\mathrm{C}$, or magnesium lith- ospermates A-C, or tanshinoates A-C., ${ }^{1,5,10,11}$ Other minor compounds include baicalin, 5,3'-dihydroxy-7,4'-dimethoxy flavanone, ursolic acid, $\beta$-sitosterol, daucosterol, vitamin $\mathrm{E}$, and tannin. ${ }^{12}$ Tanshinones and the hydrophilic Danshen compounds have been extensively investigated for their cardiovascular activities. $^{13-16}$

The chemistry, biosynthesis, and total chemical synthesis of tanshinones have been comprehensively reviewed., ${ }^{2,3}$ Figure 1B presents a summary scheme of current knowledge of the botanical chemical relationship among the major tanshinones. In our previous paper, ${ }^{17}$ we reviewed the natural and alternative sources of tanshinones and their pharmacokinetic (PK) characteristics, and provided an in-depth analysis of their anticancer activities in vitro.

The two most extensively studied tanshinones for anticancer activities are TIIA (2) and CT (1), followed by TI (4) and DH-TI (5). Some recently identified tanshinonerelated compounds ${ }^{18-21}$ including tanshinlactone (9) and neo-tanshinlactone (10, Figure 1A) appear to have greater cytotoxic potency and better selectivity than corresponding tanshinones. ${ }^{22}$ In addition to our 2012 paper, ${ }^{17}$ others have also reviewed potential anticancer properties of

A

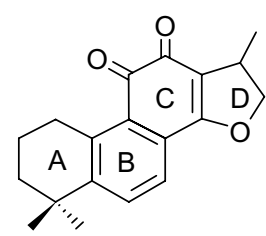

Cryptotanshinone (1)

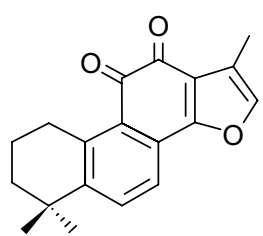

Tanshinone IIA (2)<smiles>Cc1coc2c1C(=O)C(=O)c1c-2ccc2c1CCC[C@]2(C)CO</smiles>

Tanshinone IIB (3)<smiles>Cc1coc2c1C(=O)C(=O)c1c-2ccc2c(C)cccc12</smiles>

Tanshinone I (4)<smiles></smiles>

Dihydrotanshinone I (5)<smiles>Cc1coc2c1C(=O)C(=O)c1c-2ccc2c1CC[C@@H](O)[C@@]2(C)O</smiles>

Tanshindiol B (6)<smiles>Cc1coc2c1C(=O)C(=O)c1c-2ccc2c1CC[C@@H](O)[C@]2(C)O</smiles>

Tanshindiol C (7)<smiles>COC(=O)[C@]1(C)CCCc2c1ccc1c2C(=O)C(=O)c2c(C)coc2-1</smiles><smiles>Cc1cccc2c1ccc1c3occ(C)c3c(=O)oc21</smiles>

Tanshinlactone (9)<smiles></smiles>

Neo-tanshinlactone (10)
11<smiles>CCc1cccc2c1ccc1c3occ(C)c3c(=O)oc21</smiles><smiles>COc1ccc(Nc2cc(=O)oc3c2ccc2ccccc23)cc1</smiles><smiles>Cc1cccc(Nc2cc(=O)oc3c2ccc2ccccc23)c1</smiles>

Figure I (Continued) 
B

Cryptotanshinone (1)

Tanshinone IIA (2)<smiles>CC1COC2=C1C(=O)C(=O)c1c2ccc2c1CCCC2(C)C</smiles>

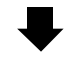<smiles>Cc1coc2c1C(=O)C(=O)c1c-2ccc2c1CCCC2(C)C</smiles>

Tanshinone IIB (3)<smiles>Cc1coc2c1C(=O)C(=O)c1c-2ccc2c1CCC[C@@]2(C)CO</smiles>

Tanshinone I (4)

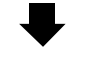<smiles>Cc1coc2c1C(=O)C(=O)c1c-2ccc2c(C)cccc12</smiles><smiles>COC(=O)c1ccc2c(C)cccc2c1C</smiles>

Dlhydrotanshinone I (5)
C<smiles>Cc1c(/C=C/C(=O)O)oc2c1C(=O)C(=O)c1c-2ccc2c1CCCC2(C)C</smiles><smiles>Cc1c(S(=O)(=O)[O-])oc2c1C(=O)C(=O)c1c-2ccc2c1CCCC2(C)C</smiles><smiles>C=C(C)C(=C)/C(=C\OC(C)=O)OC(C)=O</smiles>

Acetyl tanshinone IIA<smiles>[R6]OC[C@@]1(C)CCCc2c(O)c(O)c3c(cc(C)c4c(C)coc43)c21</smiles>

Figure I Structure of Danshen tanshinones, their likely botanical synthesis pathway, and select synthetic derivatives.

Notes: (A) Chemical structures of major tanshinones, tanshindiols, and tanshinlactones. (B) Botanical relationship among the major tanshinones in Danshen Salvia miltiorrhiza. (C) Reported structurally modified tanshinones.

Abbreviations: ROS, reactive oxygen species; TIIA, tanshinone IIA.

tanshinones from various perspectives. ${ }^{2,23}$ In the current paper, we focus on anticancer efficacy evaluation outcomes in preclinical animal models and human clinical use experiences with tanshinones and Danshen-containing TCM preparations, aiming to provide an objective assessment of the merit of these entities for future research and development.

\section{PK characteristics of tanshinones and herbal interactions The PK characteristics of singly administered tanshinones or herbal mixtures}

The PK parameters of major tanshinones (CT, TIIA, TI, DH-TI) have been studied in animal models such as rats, rabbits, and pigs, almost exclusively by scientists in the People's Republic of China. Readers are referred to our previous review for specifics. ${ }^{17}$ Some general conclusions are summarized here.
We note upfront that there were great variations among the analytical methods of extraction and detection, tanshinone dosages, and excipient solvents/vehicles used for administration that made generalization challenging.

First, being essentially insoluble in aqueous media, tanshinones are poorly bioavailable with conventional delivery formulations through oral administration (po). For example, when $\mathrm{CT}$ was dosed at $100 \mathrm{mg} / \mathrm{kg}$ body weight, the po and intraperitoneal (ip) bioavailability in rats was estimated as $2.1 \%$ and $10.6 \%$, respectively. ${ }^{24}$ Maximal/peak concentration $\left(C_{\max }\right)$ values were reported in the nanomolar to sub-micromolar range after po administration in most studies on tanshinones.

Corroborating the reported concentration ranges, we found, in a single-dose PK experiment with male C57BL/6 mice fed a AIN93M purified diet gavage-dosed $1.5 \mathrm{mg}$ TIIA/mouse (standardized to body weight of $20 \mathrm{~g} ; \sim 75 \mathrm{mg} / \mathrm{kg}$ body weight) in $200 \mu \mathrm{L}$ corn oil, that the plasma TIIA $C_{\text {max }}$ is $81.9 \mathrm{ng} / \mathrm{mL}$ $(\sim 0.28 \mu \mathrm{M})$ at time to peak concentration $=2.4$ hours (Figure 2; Wu et al, unpublished data). The mouse PK data are important 
because anticancer efficacy studies have been done almost exclusively in murine models.

Second, the plasma PK curves of most intravenous (iv)-administered tanshinones follow two-compartment or multiple-compartment models in model animals such as rats, rabbits, and pigs; that is, a very fast component with a half-life of shorter than 10 minutes that likely represents rapid uptake by organs and tissues from the blood, and a slower component with half-life ranging 1-3 hours that likely represents systemic clearance balanced by tissue-blood redistribution. In the mice, we estimated that the slower clearance half-life $T_{1 / 2}$ was 3.4 hours (Figure 2B).

As with other herbal preparations, interactions among Danshen chemicals will invariably occur after administration of tanshinone mixtures or Danshen extracts to affect their PK parameters. For example, Guo et $\mathrm{al}^{25}$ studied the interactions between tanshinones and Danshen polyphenolic extract after iv administration in the rat model. They showed that plasma TIIA concentration at 5 minutes post-iv $\left(C_{5 \min }\right)$ was significantly increased by including the salvianolic acid $\mathrm{B}$ extract in the dosing emulsion (up to 28 -fold). Another study reported that such interactions did not appear to be as dramatic when examined by oral delivery, ${ }^{26}$ perhaps a reflection of the involvement of liver first-pass metabolism of these compounds to attenuate the magnitude of their interactions.

Third, in a number of species including pigs and rats, there were reports of in vivo metabolism or biotransformation of tanshinones, especially CT to TIIA. ${ }^{27-29}$ Liu et al reported in 2013 that the glucuronidation enzyme UGT1A, in particular UGT1A9, can compromise TIIA cytotoxicity via reducing its intracellular exposure and switching the NQO1-mediated redox cycle for reactive oxygen species (ROS) generation to metabolic elimination of TIIA. ${ }^{30}$ The expression and activity of UGT1A affected the intracellular accumulation of TIIA and the severity of the apoptosis in colon cancer cells by ROS. ${ }^{30}$ Therefore, interpretation of animal efficacy studies should be made with knowledge of not only the administered tanshinone but also its in vivo metabolites and the metabolic flux.

\section{Novel formulations to improve solubility and PKs}

To overcome poor aqueous solubility of tanshinones, some groups have experimented with novel pharmaceutical formulations. Solid lipid nanoparticles (SLNs) can improve bioavailability of poorly water-soluble drugs ${ }^{31}{ }^{31}$ TIA-loaded SLNs coated with poloxamer 188 extended plasma elimination time and mean residence time of TIIA in rats and reduced opsonization by serum proteins and macrophage uptake. ${ }^{32}$ Polylactic acid nanoparticles containing TIIA exhibited better pharmaceutical effects than neat compound in mice. ${ }^{33}$ Similarly, CT administered in an SLN formulation significantly improved its absorption and decreased its metabolism to TIIA in a rat model. ${ }^{34}$ Nanoparticles made with methoxy polyethylene glycol, polylactic-co-glycolic acid, poly-L-lysine, and cyclic arginine-glycine-aspartic acid with TIIA payload demonstrated extended TIIA releasing time, and improved hepatocellular carcinoma (HCC)-inhibitory activity. ${ }^{35}$ Solid inclusion complexes of TIIA and TI with naturally occurring, water-soluble cyclic oligosaccharide $\beta$-cyclodextrins
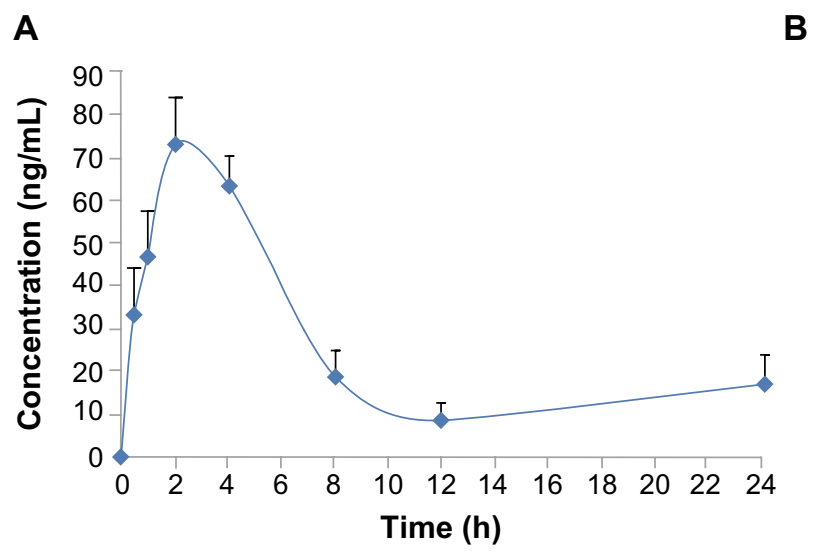

\begin{tabular}{cl}
\hline Parameters & \multicolumn{1}{c}{ TIIA } \\
\hline$t_{\max }(\mathrm{h})$ & $2.4 \pm 0.9$ \\
\hline$C_{\max }(\mu \mathrm{g} / \mathrm{L})$ & $81.9 \pm 8.2$ \\
\hline$T_{1 / 2}(\mathrm{~h})$ & $3.4 \pm 1.6$ \\
\hline $\mathrm{AUC}_{0-24 \mathrm{~h}}(\mu \mathrm{g} / \mathrm{L} \cdot \mathrm{h})$ & $5,176 \pm 3,141$ \\
\hline
\end{tabular}

Figure 2 Tanshinone IIA pharmacokinetic study in mice.

Notes: (A) Concentration-time profile of TIIA in mouse plasma after gavage administration of $75 \mathrm{mg}$ TIIA $/ \mathrm{kg}$ body weight (mean \pm SD, $\mathrm{n}=5$ ). Liquid chromatography-tandem mass spectrometry method was used for quantitation. (B) Pharmacokinetic parameters of TIIA in mice. Values are mean \pm SD ( $n=5$ ).

Abbreviations: TIIA, tanshinone IIA; SD, standard deviation; AUC, area under the curve; $t_{\text {max }}$, time to peak concentration; $C_{\text {max }}$, peak concentration; $T_{1 / 2}$, time for concentration to decrease by half. 
have been made and tested as well. ${ }^{36}$ An article published in Chinese reported a self-microemulsifying drug delivery system (SMEDDS) to increase solubility and intestinal absorption in situ of tanshinones.

Several papers since the publication of our 2012 review $^{17}$ added further novelty and refinement. For example, Ma et al encapsulated TIIA or tanshinone mixture containing TI, TIIA, TIIB, DH-TI, and CT into a microemulsion composed of phospholipid, ethyloleate, glycerol, and Pluronic F68 and found enhanced apoptosis in vitro with murine HCC models. ${ }^{37,38}$ The microemulsion exerted greater antitumor effects of both TIIA and tanshinone mixture than respective free forms in murine allograft models. ${ }^{37,38}$ In 2014, Zhang et al reported a mixed micelle system of D- $\alpha$-tocopheryl polyethylene glycol succinate-graft-poly (D, L-lactide-coglycolide) copolymer and Pluronic F68 to encapsulate TIIA. ${ }^{39}$ They showed that TIIA-loaded mixed micelles exerted higher in vitro cytotoxicity and pro-apoptotic effect than free TIIA against HCC HepG2 cells. Their PK data revealed that TIIA delivered by mixed micelles significantly prolonged the circulation time and improved its bioavailability in rats. ${ }^{39}$

In addition, chemical structural modifications were made to improve the bioavailability or bioactivity of tanshinones such as sodium tanshinone TIIA sulfonate (STS) and acetyl tanshinone IIA (ATA) (Figure 1C) (described in the "Structural modifications of tanshinones" section). Liang et al obtained two new glycosylated derivatives of TIIA by microbial transformation of TIIA using Cunninghamella elegans AS 3.2028, namely hydroquinone TIIA 11-O- $\beta$-D-glucopyranoside (TIIA 11-glu) and hydroquinone TIIA $12-\mathrm{O}-\beta$-D-glucopyranoside..$^{40}$ The solubility of TIIA 11 -glu in 50\% methanol was $\sim 50$-fold that of TIIA (84.6 vs $1.7 \mu \mathrm{g} / \mathrm{mL}$ ). PK study in mice with TIIA 11-glu after gavage administration showed detectable TIIA 11-glu and TIIA, whereas TIIA gavaged similarly did not reach the detectable level. Therefore, in addition to chemical modification approaches, biotransformation through glycosylation could increase the oral absorption of TIIA.

\section{Anticancer efficacy of tanshinones in preclinical animal models Cancer therapy or adjuvant chemoprevention models}

To date, more than 30 papers reported the evaluation of in vivo efficacy of tanshinones in preclinical animal models of cancer. Table 1 summarizes these studies. These studies used xenograft tumors or allograft tumors in mice. Routes of delivery of tanshinones varied among studies, including gavage, ip injection, iv, or even subcutaneous (sc) injection close to the tumor site. The excipient solvent vehicles involved corn oil, Tween-20:ethanol, dimethyl sulfoxide, saline, conditioned medium, and special formulations (nanoparticles, emulsions, mixed micelles), or were not described in some studies. We would caution readers to be aware of publication bias against negative efficacy outcomes that were not published and of false positive outcomes in published studies. The poor solubility of tanshinones in organic solvents, let alone aqueous media, presents tough challenges to ensure consistent and reliable delivery, and therefore, the comparability among studies from different papers is low. One should be very suspicious of studies reporting delivery of tanshinone(s) in aqueous vehicles such as saline unless special formulation was done to first disperse the tanshinone(s) into a watermiscible form.

A number of recently published studies are highlighted here. Li et $\mathrm{al}^{41}$ found that TIIA inhibited the angiogenesis and growth of MDA-MB-231 human breast cancer xenograft in athymic nude mice along with a suppression of HIF-1 $\alpha$ and VEGF. Their study suggested the mTOR/p70S6K/4EBP1 signaling pathway as a potential target for TIIA. Lin et $\mathrm{al}^{42}$ reported that TIIA decreased cell proliferation and mammosphere formation by enriched human MCF-7 breast cancer stem cells (CSCs) in vitro. In xenograft model generated with $\mathrm{CSC}$-rich $\mathrm{MCF}-7$ mammospheres, treating mice with TIIA of 10,20 , and $40 \mathrm{mg} / \mathrm{kg}$ doses by ip injection three times a week for 4 weeks inhibited tumor growth by $39 \%, 48 \%$, and $58 \%$, respectively. Similarly, by sc injection every other day, Chiu et $\mathrm{al}^{43}$ showed that TIIA 60 or $90 \mathrm{mg} /$ $\mathrm{kg}$ dissolved in corn oil suppressed $\mathrm{LNCaP}$ prostate cancer (PCa) xenograft growth by $57 \%$ and $86 \%$ after 13 days of treatment, respectively. Upregulation of GADD153/CHOP and caspase-3 activation were observed in TIIA-treated tumors, supporting endoplasmic reticulum stress induction and apoptosis in $\mathrm{PCa}$ in vivo. Munagala et $\mathrm{al}^{44}$ demonstrated a significant repression of the HPV oncogenes by TIIA in human Ca Ski epidermoid cervical cancer by ip injection of TIIA, $30 \mathrm{mg} / \mathrm{kg}$ body weight, every other day for 8 weeks, and tumor volume was inhibited by $66 \%$ in athymic nude mice. Chen et $\mathrm{al}^{45}$ used patient-derived lung cancer tissues (PDX) to engraft $\left(\sim 3 \times 3 \times 3 \mathrm{~mm}^{3}\right.$ pieces) the right hind limbs of male athymic nude mice and treated them daily with CT (100 mg/kg body weight) by sc injection around the xenotransplantation area for 20 days. They found that CT not only inhibited the growth of xenografted human lung cancer in vivo but also improved the physical and mental status of tumor-bearing mice. 
Table I Summary of in vivo efficacy studies in preclinical animal models of cancer

\begin{tabular}{|c|c|c|c|c|c|}
\hline Tanshinone & Route/frequency & Dose, range & Vehicle & Cancer model & Efficacy \\
\hline TIIA & Gavage/daily & $20 \mathrm{mg} / \mathrm{kg}$ & Corn oil & $\begin{array}{l}\text { Colo205 colon } \mathrm{Ca} \\
\text { xenograft }\end{array}$ & $Y_{e s}^{46}$ \\
\hline TIIA (plus 5F) & Gavage/twice per week & $20 \mathrm{mg} / \mathrm{kg}$ & Corn oil & $\begin{array}{l}\text { Colo205 colon } \mathrm{Ca} \\
\text { xenograft }\end{array}$ & $\mathrm{Yes}^{47}$ \\
\hline TIIA & Gavage/daily & $25 \mathrm{mg} / \mathrm{kg}$ & Corn oil & $\begin{array}{l}\text { LNCaP prostate } \mathrm{Ca} \\
\text { xenograft }\end{array}$ & Yes $^{48}$ \\
\hline TIIA & Gavage/every other day & $20,60 \mathrm{mg} / \mathrm{kg}$ & Corn oil & $\begin{array}{l}\text { MDA-MB-23I breast Ca } \\
\text { xenograft }\end{array}$ & Yes $^{49}$ \\
\hline TIIA & Gavage/daily & $20,80 \mathrm{mg} / \mathrm{kg}$ & ND & $\begin{array}{l}\text { Liver metastasis of SW } 480 \\
\text { colon } \mathrm{Ca}\end{array}$ & $Y_{e s}^{50}$ \\
\hline TIIA & Gavage/daily & $150,450,1,350 \mathrm{mg} / \mathrm{kg}$ & ND & $\begin{array}{l}\text { Lung metastasis of HepG2 } \\
\text { xenograft }\end{array}$ & $Y_{e s^{51}}$ \\
\hline TIIA & Gavage/daily & $100 \mathrm{mg} / \mathrm{kg}$ & Saline & $\begin{array}{l}\text { HSV-tk and WT BI6 } \\
\text { cells(I:9) murine melanoma }\end{array}$ & $\mathrm{No}^{52}$ \\
\hline TIIA & ip/4 times per week & $30 \mathrm{mg} / \mathrm{kg}$ & I\% Tween 20/ethanol & $\begin{array}{l}\text { MDA-MB-23I and MCF-7 } \\
\text { breast } \mathrm{Ca} \text { xenograft }\end{array}$ & $\mathrm{Yes}^{53}$ \\
\hline TIIA & ip/4 times per week & $30 \mathrm{mg} / \mathrm{kg}$ & ND & $\begin{array}{l}\text { MDA-MB-23I and MCF-7 } \\
\text { breast } \mathrm{Ca} \text { xenograft }\end{array}$ & $\mathrm{Yes}^{54}$ \\
\hline TIIA & ip/3 times per week & $10-40 \mathrm{mg} / \mathrm{kg}$ & ND & $\begin{array}{l}\text { MCF-7M (CSC) breast Ca } \\
\text { xenograft }\end{array}$ & $\mathrm{Yes}^{42}$ \\
\hline TIIA & ip/daily & $50 \mathrm{mg} / \mathrm{kg}$ & Saline & $\begin{array}{l}\text { MDA-MB-23I breast Ca } \\
\text { xenograft }\end{array}$ & $Y_{e s}^{41}$ \\
\hline TIIA & ip/every other day & $30 \mathrm{mg} / \mathrm{kg}$ & ND & $\begin{array}{l}\mathrm{HPV}+\mathrm{Ca} \text { Ski cervical Ca } \\
\text { xenograft }\end{array}$ & $\mathrm{Yes}^{44}$ \\
\hline TIIA & ip/3 times per week & $10,20,40 \mathrm{mg} / \mathrm{kg}$ & ND & $\begin{array}{l}\text { GBMS (CSC) glioma } \\
\text { xenograft }\end{array}$ & $Y_{e s}^{55}$ \\
\hline TIIA & ip/twice per week & 30 mg/kg & Corn oil & J5 Liver HCC xenograft & $Y_{e s}^{56}$ \\
\hline TIIA & ip/every other day & $20,40 \mathrm{mg} / \mathrm{kg}$ & $0.5 \% \mathrm{CMC}$ & $\begin{array}{l}\text { Ascitic-type hepatic } \mathrm{Ca} \\
\mathrm{H} 22 \text { allograft }\end{array}$ & $\mathrm{Yes}^{57}$ \\
\hline TIIA & ip/every other day & 20 mg/kg & ND & A549 lung Ca xenografts & Yes $^{58}$ \\
\hline TIIA & ip/daily & $0.3 \mathrm{mg} / \mathrm{kg}$ & TPA-CM & $\begin{array}{l}\mathrm{CLI}-5 \text { lung } \mathrm{Ca} \text { xenograft } \\
\text { and metastases }\end{array}$ & $\mathrm{No}^{59}$ \\
\hline TIIA & ip/daily & 15 mg/kg & Saline & SI 80 sarcoma xenograft & $Y_{e s}^{60}$ \\
\hline STS & ip/daily & $0.2-50 \mathrm{mg} / \mathrm{kg}$ & ND & Lewis lung $\mathrm{Ca}$ allograft & $\mathrm{No}^{61}$ \\
\hline STS & ip/daily & $\sim 50 \mathrm{mg} / \mathrm{kg}$ & Aqueous injectable & $\begin{array}{l}\text { HCCLM3 liver cancer } \\
\text { metastasis }\end{array}$ & Yes $^{62}$ \\
\hline ATA & ip/3 times per week & $30 \mathrm{mg} / \mathrm{kg}$ & ND & $\begin{array}{l}\text { MDA-MB- } 435 \text { melanoma } \\
\text { Ca xenograft }\end{array}$ & Yes $^{63}$ \\
\hline ATA & $\mathrm{ip} / 3$ times per week & $35 \mathrm{mg} / \mathrm{kg}$ & ND & $\begin{array}{l}\text { MDA-MB-435 melanoma } \\
\text { Ca xenograft }\end{array}$ & Yes $^{64}$ \\
\hline TIIA & iv/daily & $0.5-2 \mathrm{mg} / \mathrm{kg}$ & Nanoparticle & Murine hepatoma allograft & Yes $^{33}$ \\
\hline TIIA & iv/every other day & $\mathrm{I} \mathrm{mg} / \mathrm{kg}$ & Nanoparticle & Murine hepatoma allograft & $\mathrm{Yes}^{35}$ \\
\hline TIIA & iv/daily-I week only & $0.5-2 \mathrm{mg} / \mathrm{kg}$ & ND & $\begin{array}{l}\text { Murine } \mathrm{C} 26 \text { colorectal } \mathrm{Ca} \\
\text { allograft }\end{array}$ & Yes $^{65}$ \\
\hline TIIA & $\mathrm{sc} / 3$ times per week & $30 \mathrm{mg} / \mathrm{kg}$ & $0.5 \% \mathrm{CMC}$ & $\begin{array}{l}\text { Breast IDC F35 } \\
\text { xenotransplant }\end{array}$ & Yes $^{66}$ \\
\hline TIIA & sc/daily & $10,30 \mathrm{mg} / \mathrm{kg}$ & $0.5 \% \mathrm{CMC}$ & $\begin{array}{l}\text { MKN45, SGC790I gastric } \\
\text { Ca xenograft }\end{array}$ & Yes $^{67}$ \\
\hline TIIA & sc/every other day & $60,90 \mathrm{mg} / \mathrm{kg}$ & Corn oil & $\begin{array}{l}\mathrm{LNCaP} \text { prostate } \mathrm{Ca} \\
\text { xenograft }\end{array}$ & $\mathrm{Yes}^{43}$ \\
\hline CT & Gavage/daily & $150 \mathrm{mg} / \mathrm{kg}$ & $0.1 \%$ SDS & $\begin{array}{l}\text { MCF-7 breast } \mathrm{Ca} \\
\text { xenograft }\end{array}$ & Yes $^{68}$ \\
\hline CT & ip/every other day & $2.5 \mathrm{mg} / \mathrm{kg}$ & $3 \%$ DMSO, 30\% PEG & $\begin{array}{l}\mathrm{HCTI} \text { I6 colorectal } \mathrm{Ca} \\
\text { xenograft }\end{array}$ & Yes $^{69}$ \\
\hline CT & ip/every other day & $5,25 \mathrm{mg} / \mathrm{kg}$ & Corn oil & $\begin{array}{l}22 \mathrm{RvI} \text { prostate } \mathrm{Ca} \\
\text { xenograft }\end{array}$ & Yes $^{70}$ \\
\hline CT & ip/every other day & $25 \mathrm{mg} / \mathrm{kg}$ & ND (corn oila) & $\begin{array}{l}22 \mathrm{Rv} l \text { prostate } \mathrm{Ca} \\
\text { metastasis }\end{array}$ & $Y_{e s}{ }^{71}$ \\
\hline
\end{tabular}


Table I (Continued)

\begin{tabular}{|c|c|c|c|c|c|}
\hline Tanshinone & Route/frequency & Dose, range & Vehicle & Cancer model & Efficacy \\
\hline$\overline{C T}$ & ip/every other day & $10 \mathrm{mg} / \mathrm{kg}$ & $2 \%$ Tween 80 & PC-3 prostate $\mathrm{Ca}$ xenograft & Yes $^{72}$ \\
\hline CT & sc/daily, near tumor & 100 mg/kg & ND & Human lung cancer PDX & $Y_{e s}{ }^{45}$ \\
\hline TI & Gavage/daily & $150 \mathrm{mg} / \mathrm{kg}$ & Corn oil & $\begin{array}{l}\text { DUI } 45 \text { prostate } \mathrm{Ca} \\
\text { xenograft }\end{array}$ & Yes $^{73}$ \\
\hline $\mathrm{TI}$ & Gavage/daily & $80,200 \mathrm{mg} / \mathrm{kg}$ & Corn oil & HI 299 lung $\mathrm{Ca}$ xenograft & Yes $^{74}$ \\
\hline $\mathrm{TI}$ & ip/daily & $10 \mathrm{mg} / \mathrm{kg}$ & ND & $\begin{array}{l}\text { Lung metastasis/MDA- } \\
\text { MB-23I breast } \mathrm{Ca}\end{array}$ & Yes $^{75}$ \\
\hline $\mathrm{TI}$ & ip/daily & $0.3 \mathrm{mg} / \mathrm{kg}$ & TPA-CM & $\begin{array}{l}\mathrm{CLI}-5 \text { lung } \mathrm{Ca} \text { xenograft } \\
\text { and metastases }\end{array}$ & $Y_{e s}^{59}$ \\
\hline TI & ip/3 times per week & $\mathrm{l}$ mg/kg & CM & Transgenic lung $\mathrm{Ca}$ allograft & Yes $^{76}$ \\
\hline $\mathrm{DH}-\mathrm{TI}$ & ip/3 times per week & $10 \mathrm{mg} / \mathrm{kg}$ & DMSO & $\begin{array}{l}\text { MDA-MB-23I breast Ca } \\
\text { xenograft }\end{array}$ & Yes $^{77}$ \\
\hline $\mathrm{DH}-\mathrm{TI}$ & ip before radiation & $10 \mathrm{mg} / \mathrm{kg}$ & $<0.5 \%$ DMSO & HeLa cervical Ca xenograft & $Y_{e s}{ }^{78}$ \\
\hline $\mathrm{DH}-\mathrm{TI}$ & ip/3 times per week & 10 mg/kg & Liposome & AGS gastric Ca xenograft & Yes $^{79}$ \\
\hline Tanshinone Mix & iv/daily & $2-8 \mathrm{mg} / \mathrm{kg}$ & Microemulsion & $\begin{array}{l}\text { H22 murine hepatoma } \\
\text { allograft }\end{array}$ & $Y_{e s}^{37}$ \\
\hline TIIA & ip/daily & $24 \mathrm{mg} / \mathrm{kg}$ & Corn oil & $\begin{array}{l}\text { Rat benign prostatic } \\
\text { hyperplasia }\end{array}$ & $Y_{e s}{ }^{80}$ \\
\hline TIIA & Gavage/daily & $\sim 60-75 \mathrm{mg} / \mathrm{kg}$ & Corn oil & $\begin{array}{l}\text { TRAMP mouse } \\
\text { carcinogenesis } \\
\text { (current study) }\end{array}$ & No \\
\hline
\end{tabular}

Notes: aLikely corn oil per other report from same group. ${ }^{70}$ bPatient-derived xenograft in athymic nude mice.

Abbreviations: TIIA, tanshinone IIA; ND, not described; ip, intraperitoneal; CMC, carboxyl methyl cellulose; TPA-CM, tetradecanoyl phorbol acetate conditioned medium; STS, sodium tanshinone TIIA sulfonate; ATA, acetyl tanshinone IIA; iv, intravenous; sc, subcutaneous; CT, cryptotanshinone; SDS, sodium dodecyl sulfate; DMSO, dimethyl sulfoxide; PEG, polyethylene glycol; TI, tanshinone I; CM, conditioned medium; DH-TI, dihydrotanshinone I.

A common feature of these efficacy studies was using parenteral injections to deliver the tanshinones rather than gastrointestinal route. The gastrointestinal route is more practical and desirable for cancer chemopreventive agent administration for the long term.

\section{Primary cancer chemoprevention model}

We have recently used a transgenic prostate carcinogenesis model (transgenic adenocarcinoma of mouse prostate, TRAMP) to evaluate the in vivo chemoprevention efficacy of TIIA. In this study, in-house-bred male C57BL/6 TRAMP mice and their wild-type littermates received TIIA $(1.5 \mathrm{mg} /$ mouse in corn oil; $\sim 60-75 \mathrm{mg} / \mathrm{kg}$ body weight) by gavage once daily, 5 days a week, from 8 to 28 weeks of age. We found that TIIA gavage neither affected the neuroendocrine-carcinoma lineage burden in the TRAMP mice model nor inhibited the growth of epithelial lesions estimated by prostate weight (Table 2). We detected plasma level of TIIA of $98( \pm 30.9$ standard deviation) $\mathrm{ng} / \mathrm{mL}(\sim 0.33 \mu \mathrm{M})$ by liquid chromatography-tandem mass spectrometry method at 4 hours after the last dose. These results combined with our PK data of the same dosage (Figure 2) indicated that either the threshold level of TIIA was not achieved through the route and dose/ form of delivery to exert in vivo efficacy or the TRAMP prostate carcinogenesis model was refractory to TIIA in both the epithelial lesion and neuroendocrine lineages.

Concerning androgen-driven prostate epithelial hyperproliferation, in a study published in 2015, Wang et al reported the efficacy of TIIA in the treatment of a rat model of benign prostatic hyperplasia, ${ }^{80}$ a noncancerous epithelial

Table 2 Gavage administration of $1.5 \mathrm{mg}$ TIIA/mouse $(\sim 60-75 \mathrm{mg} / \mathrm{kg})$ daily did not decrease TRAMP prostate weights or NE-Ca burden by 28 weeks

\begin{tabular}{|c|c|c|c|c|c|c|c|}
\hline Group & $\begin{array}{l}\text { Genotype of } \\
\text { the mice }\end{array}$ & $\begin{array}{l}\text { Gavage began at } \\
8 \text { weeks of age }\end{array}$ & $\begin{array}{l}\text { Number of mice } \\
\text { sacrificed by } 28 \\
\text { weeks of age }\end{array}$ & $\begin{array}{l}\text { Final body } \\
\text { weight }(g)^{a}\end{array}$ & $\begin{array}{l}\text { Prostate } \\
\text { weight (mg) }\end{array}$ & $\begin{array}{l}\text { Number } \\
\text { of NE-Ca }\end{array}$ & $\begin{array}{l}\text { Total NE-Ca } \\
\text { burden }(\mathrm{g})^{\mathrm{b}}\end{array}$ \\
\hline I & TRAMP & Vehicle - corn oil & 19 & $26.8 \pm 2.31$ & $150 \pm 29$ & $4(20 \%)$ & 19.4 \\
\hline 2 & TRAMP & TIIA, 1.5 mg/mouse & 20 & $27.4 \pm 2.2$ & $161 \pm 38$ & $5(25 \%)$ & 19.9 \\
\hline 3 & Wild type & Vehicle - corn oil & 10 & $27.3 \pm 1.7$ & $78 \pm 13$ & 0 & - \\
\hline 4 & Wild type & TIIA, I.5 mg/mouse & 5 & $28.4 \pm 1.5$ & $79 \pm 18$ & 0 & - \\
\hline
\end{tabular}

Notes: aMean \pm SD. ${ }^{b}$ Summation of individual tumor weights of each group.

Abbreviations: TIIA, tanshinone IIA; TRAMP, transgenic adenocarcinoma of mouse prostate; NE-Ca, neuroendocrine-carcinoma; SD, standard deviation. 
hyperproliferative condition driven by dihydrotestosterone in man. In the rat model of estradiol/testosterone-induced benign prostatic hyperplasia, TIIA ( $24 \mathrm{mg} / \mathrm{kg}$ body weight, in corn oil, ip daily for 4 weeks) inhibited the growth of prostate stromal and epithelial cells in vivo by a mechanism that involved downregulating ER $\alpha$ and androgen receptor (AR) expression (Table 1). ${ }^{80}$

\section{Structural modifications of tanshinones}

Researchers have made structural modifications to improve the solubility and intestinal absorption of some tanshinones and/or to enhance selective cytotoxicity against cancer cells. Chinese scientists made STS as a water-soluble derivative of TIIA (Figure 1C). In fact, STS has been widely used to treat patients with cardiovascular diseases, likely through its antioxidant activities, for more than 3 decades. ${ }^{81-84}$ STS possesses a broad range of pharmacological functions including protecting the myocardium by attenuating hypertrophy, immune-mediated liver injury via modulating NF- $\kappa$ B and IFN- $\gamma /$ STAT 1 pathways, and exhibiting a strong vasodilating effect against vasoconstriction by activating conductance $\mathrm{Ca}^{2+}$-sensitive $\mathrm{K}^{+}$channels. ${ }^{85}$

However, STS was not active to induce apoptosis in several cancer cell lines. ${ }^{61,86}$ Therefore, ATA (Figure 1C) was synthesized and tested. ${ }^{63,64}$ Compared to TIIA, ATA exhibited increased water solubility and stronger apoptotic activity on multiple cancer cell lines, including HER2/Neupositive cancer cells. The stronger apoptosis effect of ATA was attributed to mitochondrial redox-ROS generation. ${ }^{63}$ Its in vivo efficacy against MDA-MB-435 (now a confirmed melanoma cell line) xenograft growth in mice was demonstrated at a dose of $30 \mathrm{mg} / \mathrm{kg}$ body weight by ip injection, three times per week.

$\mathrm{Xu}$ et al synthesized a new sodium derivative of CT, PTS33, to target AR pathway. ${ }^{87}$ PTS33 selectively inhibited AR activities but did not repress the activities of other nuclear receptors, including ER $\alpha$, glucocorticoid receptor, and progesterone receptor. PTS33 suppressed the growth of AR-positive PCa cells, and had little effect on AR-negative PCa cells. PTS33 also modulated AR transactivation and suppressed AR target genes PSA, TMPRSS2, and TMEPA1 in castration-resistant LNCaP C4-2 cells. In addition, PTS33 inhibited estrogen/ $\Delta 5$-androstenediol-induced AR activities. Further mechanistic studies indicated that PTS33 inhibited AR function by suppression of AR protein expression, AR N-C interaction, and AR co-regulator interaction.

\section{Cell culture-based studies: potential mechanisms}

Most cell culture models used concentrations without regard to in vivo achievable tanshinone levels, and therefore, the mechanistic relevance of such studies should be cautiously appreciated. As discussed in the tanshinone PK section, plasma levels of nanomolar to sub-micromolar ranges were commonly observed with oral or ip dosing. One should regard "mechanisms" derived from cell culture studies with exposure levels of $>10 \mu \mathrm{M}$ with suspicion. However, be cognizant that localized targeted delivery through novel formulations may make such exposure levels possible. We discussed the reported cellular and molecular activities of tanshinones in nine impact categories (updated in Figure 3) in our 2012 review, ${ }^{17}$ and we refer readers to that paper for "mechanistic" details. Here we discuss only a new impact category of recent findings of effects of TIIA on CSCs.

\section{Effect on CSCs}

Lin et $\mathrm{al}^{42}$ found that TIIA decreased mammosphere formation by human breast CSCs enriched from MCF-7 cell line in vitro. The CSC growth suppression was associated with decreased expression of IL-6, STAT3, phospho-STAT3 (Tyr705), NF-kBp65 in nucleus, and cyclin D1 protein. ${ }^{42}$ In a xenograft model generated with $\mathrm{MCF}-7$ mammosphere cells, treating mice with TIIA of 10,20 , and $40 \mathrm{mg} / \mathrm{kg}$ doses by ip injection three times a week for 4 weeks inhibited tumor growth by $39 \%, 48 \%$, and $58 \%$, respectively. ${ }^{42}$ In glioblastoma multiforme model, TIIA exerted a significant inhibitory effect on human glioma stem cells (GSCs) in vitro and in vivo. ${ }^{55}$ TIIA increased the expression of differentiation and neural lineage markers including GFAP and $\beta$-tubulin, decreased expression of GSC markers including CD133 and nestin, and induced GSC apoptosis. The IL-6/STAT3 signaling axis was likely targeted by TIIA to mediate the growth inhibition of GSCs. In contrast to CSCs, TIIA promotes stem cell functions in cardiovascular injury and other epithelial skin cells. ${ }^{88,89}$

\section{Cancer-related clinical studies}

Table 3 summarizes reported clinical experience with TIIA or Danshen-containing TCM formula for cancer. The clinical use of TIIA was described in two single-case reports. The first case was published in 2006 and involved a 30-year-old man diagnosed with acute promyelocytic leukemia. ${ }^{90}$ Alltrans retinoic acid differentiation therapy $(20 \mathrm{mg}$, three times per day) was administered for 14 days but did not achieve complete remission (CR). He was given oral TIIA, $30 \mathrm{mg}$, 


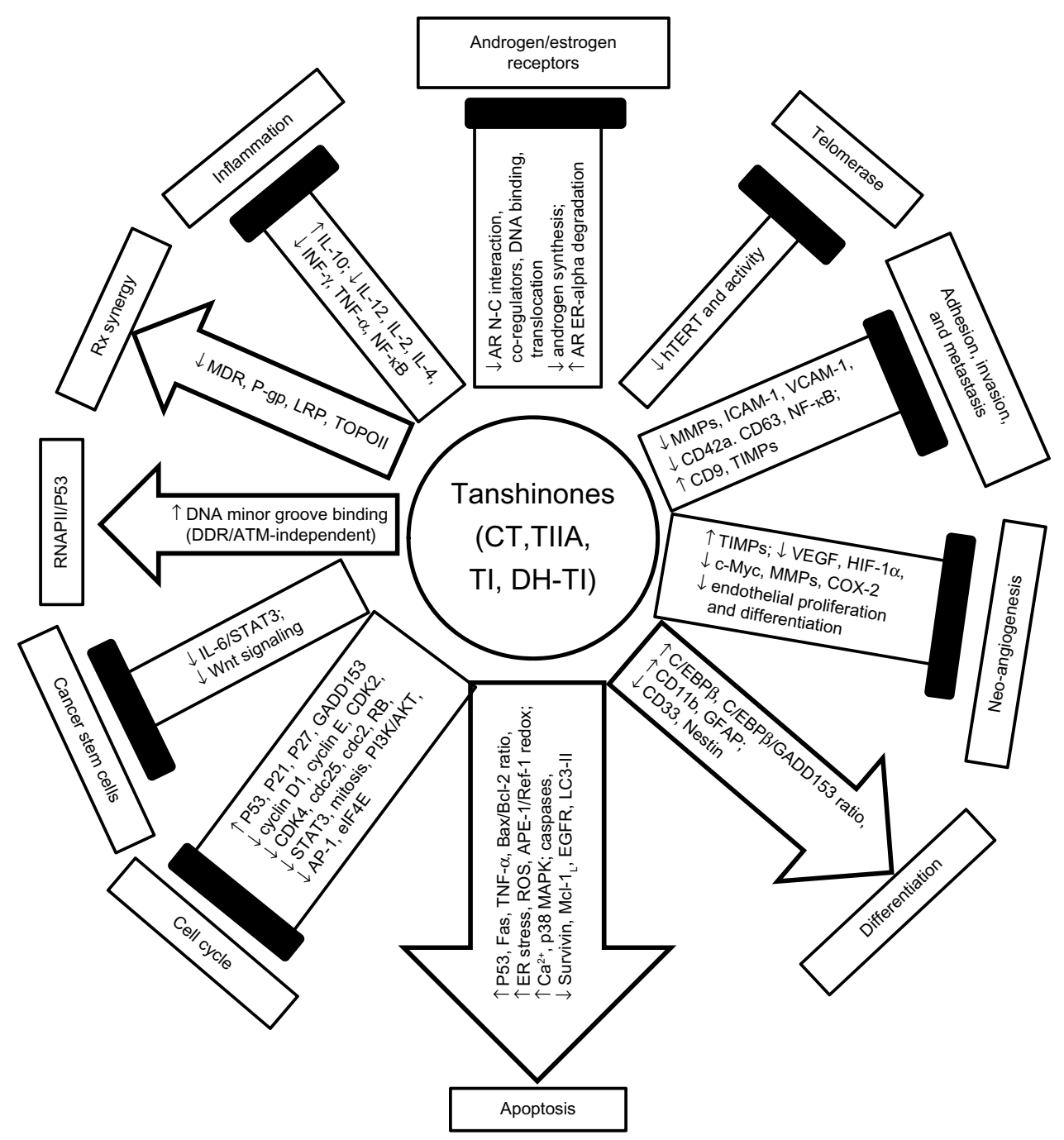

Figure 3 Summary of reported cellular and molecular effects of tanshinones in cell culture models related to cancer or its microenvironments.

Notes: Arrows indicate induction effects, and block $T(\perp)$ indicates suppression effects. Upward arrow indicates upregulation or activation, and downward arrow indicates downregulation or inactivation. Adapted from Zhang Y, Jiang P, Ye M, Kim SH, Jiang C, Lu J. Tanshinones: sources, pharmacokinetics and anti-cancer activities. International Journal of Molecular Sciences. 2012;13(10):1362I-13666. ${ }^{17}$

Abbreviations: CT, cryptotanshinone; TIIA, tanshinone IIA; TI, tanshinone I; DH-TI, dihydrotanshinone I; ROS, reactive oxygen species; CSC, cancer stem cells.

twice per day. His blood cell count at 8 weeks and bone marrow cell counts at 12 weeks were restored to normal levels, indicating a CR. Another case reported a 21-year-old man with relapsed acute promyelocytic leukemia after 1 year of all-trans retinoic acid, arsenic trioxide, 6-mercaptopurine, and methotrexate treatments. ${ }^{91}$ After 54 days of TIIA iv infusion, $80 \mathrm{mg}$ once per day, he achieved completely morphological remission without obvious side effects. ${ }^{91}$ Well-designed clinical trials with more patients and randomized placebocontrolled design are needed to further validate the clinical efficacy of TIIA and other tanshinones.

Small-scale trials found improved quality of life and overall response rates $(\mathrm{CR}+$ partial remission + stable disease) of therapeutic modalities when combined with Fufang Danshen (composite) Dripping Pills (oral intake) against gastric carcinoma, ${ }^{92}$ colorectal carcinoma, ${ }^{93}$ esophageal carcinoma, ${ }^{94}$ pancreatic carcinoma, ${ }^{95}$ liver carcinoma, ${ }^{96}$ and non-small-cell lung carcinoma ${ }^{97}$ (Table 3 ). Combining these trials for a meta-analysis would suggest a statistical and meaningful health benefit on enhancing objective response (CR + partial remission) by the Dripping Pill use. By liquid chromatography-tandem mass spectrometry analyses, ${ }^{101}$ Dripping Pills contained none to barely detectable TIIA and DH-TI and a small amount of CT and TI (2.7-5.5 $\mu \mathrm{g}$ per pill).

Compared to chemotherapy alone, Fufang Danshen Injection (injectable formula made from aqueous extracts of Danshen and one or more medicinal herbs) attenuated chemotherapy-induced complications and increased the CR rate for acute leukemia. ${ }^{98}$ Because of water extraction 
Table 3 Cancer-related clinical studies of TIIA and Danshen-containing formulas

\begin{tabular}{|c|c|c|c|c|c|}
\hline $\begin{array}{l}\text { Tanshinone tested/ } \\
\text { tanshinone- } \\
\text { containing formula }\end{array}$ & Cancers & Treatment(s) & $\begin{array}{l}\text { Number of } \\
\text { patients }\end{array}$ & Clinical benefit & References \\
\hline TIIA & Leukemia & $\begin{array}{l}\text { TIIA ( } 30 \text { mg, po, twice per day for } 3 \\
\text { months) }\end{array}$ & $\begin{array}{l}\text { Single-case } \\
\text { report }\end{array}$ & $\mathrm{CR}$ & 90 \\
\hline TIIA & Leukemia & $\begin{array}{l}\text { TIIA ( } 80 \text { mg, iv once per day for } 54 \\
\text { days) }\end{array}$ & $\begin{array}{l}\text { Single-case } \\
\text { report }\end{array}$ & $\mathrm{CR}$ & 91 \\
\hline $\begin{array}{l}\text { Fufang (composite) } \\
\text { Danshen Dripping Pills }\end{array}$ & $\begin{array}{l}\text { Gastric } \\
\text { carcinoma }\end{array}$ & $\begin{array}{l}\text { Control: chemotherapy only; } \\
\text { treatment: chemotherapy plus Fufang } \\
\text { Danshen Dripping Pill ( } 250 \mathrm{mg} \text {, po } 3 \\
\text { times per day for } 3 \text { weeks) }\end{array}$ & Treatment: 46 & $\begin{array}{l}C R+P R \text { rate (control } \\
\text { vs treatment): } 36.4 \% \text { vs } \\
41.3 \%(P>0.05) \\
C R+P R+S D \text { rate } \\
43.2 \% \text { vs } 67.4 \%(P<0.05)\end{array}$ & 92 \\
\hline $\begin{array}{l}\text { Fufang (composite) } \\
\text { Danshen Dripping Pills }\end{array}$ & $\begin{array}{l}\text { Colorectal } \\
\text { carcinoma }\end{array}$ & $\begin{array}{l}\text { Control: chemotherapy only; } \\
\text { treatment: chemotherapy plus Fufang } \\
\text { Danshen Dripping Pill ( } 250 \mathrm{mg} \text {, po } 3 \\
\text { times per day for } 3 \text { weeks) }\end{array}$ & Treatment: 47 & $\begin{array}{l}C R+P R \text { rate (control } \\
\text { vs treatment): } 41.3 \% \text { vs } \\
51.1 \%(P>0.05) \\
C R+P R+S D \text { rate } \\
58.7 \% \text { vs } 80.8 \% \\
(P<0.05)\end{array}$ & 93 \\
\hline $\begin{array}{l}\text { Fufang (composite) } \\
\text { Danshen Dripping Pills }\end{array}$ & $\begin{array}{l}\text { Esophageal } \\
\text { carcinoma }\end{array}$ & $\begin{array}{l}\text { Control: chemotherapy only; } \\
\text { treatment: chemotherapy plus Fufang } \\
\text { Danshen Dripping Pill ( } 250 \mathrm{mg} \text {, po } 3 \\
\text { times per day for } 3 \text { weeks) }\end{array}$ & Treatment: 36 & $\begin{array}{l}C R+P R \text { rate (control } \\
\text { vs treatment): } 38.2 \% \text { vs } \\
52.8 \%(P>0.05) \\
C R+P R+S D \text { rate } \\
52.9 \% \text { vs } 80.6 \%(P<0.05)\end{array}$ & 94 \\
\hline $\begin{array}{l}\text { Fufang (composite) } \\
\text { Danshen Dripping Pills }\end{array}$ & $\begin{array}{l}\text { Pancreatic } \\
\text { carcinoma }\end{array}$ & $\begin{array}{l}\text { Control: chemotherapy only; } \\
\text { treatment: chemotherapy plus Fufang } \\
\text { Danshen Dripping Pill ( } 250 \mathrm{mg} \text {, po } 3 \\
\text { times per day for } 2 \text { weeks) }\end{array}$ & $\begin{array}{l}\text { Control: } 40 \\
\text { Treatment: } 4 \text { I }\end{array}$ & $\begin{array}{l}C R+P R \text { rate (control } \\
\text { vs treatment): } 35.0 \% \text { vs } \\
46.3 \%(P>0.05) \\
C R+P R+S D \text { rate } \\
50.0 \% \text { vs } 73.2 \%(P<0.05)\end{array}$ & 95 \\
\hline $\begin{array}{l}\text { Fufang (composite) } \\
\text { Danshen Dripping Pills }\end{array}$ & $\begin{array}{l}\text { Liver } \\
\text { carcinoma }\end{array}$ & $\begin{array}{l}\text { Control: chemotherapy only; } \\
\text { treatment: chemotherapy plus Fufang } \\
\text { Danshen Dripping Pill ( } 250 \mathrm{mg} \text {, po } 3 \\
\text { times per day for } 3 \text { weeks) }\end{array}$ & Treatment: 49 & $\begin{array}{l}C R+P R \text { rate (control } \\
\text { vs treatment): } 61.7 \% \text { vs } \\
69.4 \%(P>0.05) \\
C R+P R+S D \text { rate } \\
70.2 \% \text { vs } 89.8 \%(P<0.05)\end{array}$ & 96 \\
\hline $\begin{array}{l}\text { Fufang (composite) } \\
\text { Danshen Dripping Pills }\end{array}$ & $\begin{array}{l}\text { Non-small- } \\
\text { cell lung } \\
\text { carcinoma }\end{array}$ & $\begin{array}{l}\text { Control: chemotherapy only; } \\
\text { treatment: chemotherapy plus Fufang } \\
\text { Danshen Dripping Pill ( } 250 \mathrm{mg} \text {, po } 3 \\
\text { times per day for } 2 \text { weeks) }\end{array}$ & Treatment: 45 & $\begin{array}{l}C R+P R \text { rate (control } \\
\text { vs treatment): } 34.9 \% \text { vs } \\
46.7 \%(P>0.05) \\
C R+P R+S D \text { rate } \\
62.8 \% \text { vs } 84.4 \%(P<0.05)\end{array}$ & 97 \\
\hline $\begin{array}{l}\text { Fufang (composite) } \\
\text { Danshen Injection }\end{array}$ & Leukemia & $\begin{array}{l}\text { Control: chemotherapy only; } \\
\text { treatment: chemotherapy plus Fufang } \\
\text { Danshen Injection ( } 20-30 \mathrm{~mL} \text {, iv, } \\
\text { once per day for } 28 \text { days) }\end{array}$ & $\begin{array}{l}\text { Control: } 46 \\
\text { Treatment: } 86\end{array}$ & $\begin{array}{l}\text { Fufang Danshen slightly } \\
\text { increased CR rate but } \\
\text { significantly attenuated } \\
\text { the side effects of } \\
\text { chemotherapy }\end{array}$ & 98 \\
\hline $\begin{array}{l}\text { Fufang (composite) } \\
\text { Danshen Injection }\end{array}$ & $\begin{array}{l}\text { Liver } \\
\text { carcinoma }\end{array}$ & $\begin{array}{l}\text { Control: surgical resection only; } \\
\text { treatment: surgical resection plus } \\
\text { chemotherapy and Fufang Danshen } \\
\text { Injection ( } 250 \mathrm{~mL} \text {, TUV perfusion, } \\
\text { once per day for } 7 \text { days, repeat } \\
\text { every 3-4 weeks) }\end{array}$ & $\begin{array}{l}\text { Control: } 30 \\
\text { Treatment: } 30\end{array}$ & $\begin{array}{l}\text { I- and } 2 \text {-year recurrence } \\
\text { rates (control vs } \\
\text { treatment): } 60.7 \% \text { vs } \\
\text { I5.3\% }(P<0.05) \text { and } \\
75.1 \% \text { vs } 30.0 \%(P<0.05)\end{array}$ & 99 \\
\hline $\begin{array}{l}\text { Fufang (composite) } \\
\text { Danshen Injection }\end{array}$ & $\begin{array}{l}\text { Liver } \\
\text { carcinoma }\end{array}$ & $\begin{array}{l}\text { Control: TACE only; treatment: } \\
\text { TACE plus Fufang Danshen Injection } \\
\text { (16 mL, iv once per day for } 7 \text { days) }\end{array}$ & $\begin{array}{l}\text { Control: } 37 \\
\text { Treatment: } 53\end{array}$ & $\begin{array}{l}\text { I-, } 2 \text {-, and } 3 \text {-year } \\
\text { survival rate (control } \\
\text { vs treatment): } 73.0 \% \text { vs } \\
79.3 \%(P>0.05), 43.2 \% \\
\text { vs } 66.0 \%(P<0.05) \text { and } \\
24.3 \% \text { vs } 45.3 \% \\
(P<0.05)\end{array}$ & 100 \\
\hline
\end{tabular}

Abbreviations: TIIA, tanshinone IIA; TCM, Traditional Chinese Medicine; po, oral administration; CR, complete remission; iv, intravenous; PR, partial remission; SD, stable disease; TUV, trans-umbilical-portal vein; TACE, transcatheter arterial chemoembolization. 
procedures, such injectables were essentially free of hydrophobic tanshinones. Fufang Danshen Injection plus chemotherapeutic drug mitomycin and adriamycin through trans-umbilical-portal vein perfusion after surgical resection of the primary liver carcinomas significantly delayed the 1- and 2-year recurrence rates compared to the surgical resection alone. ${ }^{99}$ Furthermore, combination of hepatic artery perfusion of Fufang Danshen Injection with liver transcatheter arterial chemoembolization improved the survival and life quality of patients with HCC compared to transcatheter arterial chemoembolization alone. ${ }^{100}$

Cancer-related clinical studies in People's Republic of China suggested potential benefit of TIIA and Danshencontaining TCM formulas for cancer patients and improvement of side effect profiles and quality of life; yet, most of these studies had serious limitations, such as single-case reports, small sample size for Phase II trials ( $\mathrm{N} \leq 40)$, lack of randomization and placebo control and blinding in trial designs, and poorly defined dose-formulation information and content of tanshinones used.

\section{Conclusion and future directions}

In cell culture models, tanshinones exhibit broad-range anticancer activities including anti-proliferation, proapoptosis, anti-angiogenesis, induction of differentiation, and inhibition of adhesion, migration, invasion, and metastasis, and may sensitize cancer cells to apoptosis by current therapeutic modalitites ${ }^{17}$ and inhibit CSCs (Figure 3). ${ }^{42,55}$ Tanshinones may also modulate inflammatory and immune responses, inhibit telomerase, interact with DNA minor groove to activate P53 tumor suppressor, or regulate specific pathways such as AR (eg, TIIA, CT) or STAT3 (eg, CT), and endoplasmic reticulum stress and cancer cellular energetics ${ }^{17}$ (Figure 3). However, in vivo potency evaluation outcomes so far varied greatly due to lack of uniformity of excipients, doses, and routes of administration. One major challenge for efficacy evaluation is the poor water solubility and oral bioavailability of natural tanshinones. The ongoing pharmaceutical approach through nanoparticle- or lipid-based delivery formulations can help to improve the delivery and bioavailability of tanshinones and consequently efficacy evaluation as demonstrated in a few studies already. The chemical modification approaches have resulted in improved water solubility in all cases and improved anticancer efficacy in some instances such as ATA $^{63,64}$ and PTS $33^{87}$ but inactivated apoptosis potency in others such as STS. ${ }^{86}$ In the future, formulation optimization combined with animal PK modeling followed by rigorous safety and efficacy testing in relevant animal cancer models will improve decision making on the clinical translation worthiness of tanshinones.

\section{Acknowledgments}

This work was supported in part by NIH National Center for Complementary and Integrative Health grant AT007395 and National Cancer Institute grant CA136953 Diligent efforts were made whenever possible to reach the primary Chinese language literature. We regret omissions of articles when data were not available for evaluation for this review.

\section{Disclosure}

The authors report no conflicts of interest in this work.

\section{References}

1. Zhou L, Zuo Z, Chow MS. Danshen: an overview of its chemistry, pharmacology, pharmacokinetics, and clinical use. Journal of Clinical Pharmacology. 2005;45(12):1345-1359.

2. Dong Y, Morris-Natschke SL, Lee KH. Biosynthesis, total syntheses, and antitumor activity of tanshinones and their analogs as potential therapeutic agents. Natural Product Reports. 2011;28(3): 529-542.

3. Wang X, Morris-Natschke SL, Lee KH. New developments in the chemistry and biology of the bioactive constituents of Tanshen. Medicinal Research Reviews. 2007;27(1):133-148.

4. Nakao M, Fukushima T. On the chemical composition of Salvia miltiorrhiza (Chinese drug Tan-shen). Yakugaku Zasshi. 1934;54:844-858.

5. Bi HC, Zuo Z, Chen X, et al. Preclinical factors affecting the pharmacokinetic behaviour of tanshinone IIA, an investigational new drug isolated from Salvia miltiorrhiza for the treatment of ischaemic heart diseases. Xenobiotica. 2008;38(2):185-222.

6. Don MJ, Shen CC, Syu WJ, Ding YH, Sun CM. Cytotoxic and aromatic constituents from Salvia miltiorrhiza. Phytochemistry. 2006;67(5):497-503.

7. Gu M, Zhang G, Su Z, Ouyang F. Identification of major active constituents in the fingerprint of Salvia miltiorrhiza Bunge developed by highspeed counter-current chromatography. Journal of Chromatography A. 2004;1041(1-2):239-243.

8. Wei YJ, Li SL, Li P. Simultaneous determination of seven active components of Fufang Danshen tablet by high performance liquid chromatography. Biomedical Chromatography. 2007;21(1): 1-9.

9. Yang M, Liu A, Guan S, Sun J, Xu M, Guo D. Characterization of tanshinones in the roots of Salvia miltiorrhiza (Dan-shen) by highperformance liquid chromatography with electrospray ionization tandem mass spectrometry. Rapid Communications in Mass Spectrometry. 2006;20(8):1266-1280.

10. Liu AH, Li L, Xu M, Lin YH, Guo HZ, Guo DA. Simultaneous quantification of six major phenolic acids in the roots of Salvia miltiorrhiza and four related traditional Chinese medicinal preparations by HPLCDAD method. Journal of Pharmaceutical and Biomedical Analysis. 2006;41(1):48-56.

11. Ma L, Zhang X, Guo H, Gan Y. Determination of four water-soluble compounds in Salvia miltiorrhiza Bunge by high-performance liquid chromatography with a coulometric electrode array system. Journal of Chromatography B: Analytical Technologies in the Biomedical and Life Sciences. 2006;833(2):260-263.

12. Kong DY. Chemical constituents of Salvia miltiorrhiza (Danshen). Zhongguo Yiyao Gongye Zazhi. 1989;20:279-285. 
13. Zeng Y, Song JX, Shen XC. Herbal remedies supply a novel prospect for the treatment of atherosclerosis: a review of current mechanism studies. Phytotherapy Research: PTR. 2012;26(2): $159-167$.

14. Gao S, Liu Z, Li H, Little PJ, Liu P, Xu S. Cardiovascular actions and therapeutic potential of tanshinone IIA. Atherosclerosis. 2012;220(1):3-10.

15. Ho JH, Hong CY. Salvianolic acids: small compounds with multiple mechanisms for cardiovascular protection. Journal of Biomedical Science. 2011;18:30.

16. Jia Y, Huang F, Zhang S, Leung SW. Is danshen (Salvia miltiorrhiza) dripping pill more effective than isosorbide dinitrate in treating angina pectoris? A systematic review of randomized controlled trials. International Journal of Cardiology. 2012;157(3): 330-340.

17. Zhang Y, Jiang P, Ye M, Kim SH, Jiang C, Lu J. Tanshinones: sources, pharmacokinetics and anti-cancer activities. International Journal of Molecular Sciences. 2012;13(10):13621-13666.

18. Wang X, Nakagawa-Goto K, Bastow KF, et al. Antitumor agents. 254. Synthesis and biological evaluation of novel neo-tanshinlactone analogues as potent anti-breast cancer agents. Journal of Medicinal Chemistry. 2006;49(18):5631-5634.

19. Sashidhara KV, Rosaiah JN, Kumar M, et al. Neo-tanshinlactone inspired synthesis, in vitro evaluation of novel substituted benzocoumarin derivatives as potent anti-breast cancer agents. Bioorganic and Medicinal Chemistry Letters. 2010;20(23):7127-7131.

20. Dong Y, Shi Q, Pai HC, et al. Antitumor agents. 272. Structure-activity relationships and in vivo selective anti-breast cancer activity of novel neo-tanshinlactone analogues. Journal of Medicinal Chemistry. 2010;53(5):2299-2308.

21. Dong Y, Nakagawa-Goto K, Lai CY, Morris-Natschke SL, Bastow KF, Lee KH. Antitumor agents 287. Substituted 4-amino-2H-pyran-2-one (APO) analogs reveal a new scaffold from neo-tanshinlactone with in vitro anticancer activity. Bioorganic and Medicinal Chemistry Letters. 2011;21(8):2341-2344.

22. Wang X, Bastow KF, Sun C-M, et al. Antitumor agents. 239. Isolation, structure elucidation, total synthesis, and anti-breast cancer activity of neo-tanshinlactone from Salvia miltiorrhiza. Journal of Medicinal Chemistry. 2004;47(23):5816-5819.

23. Tian $\mathrm{XH}, \mathrm{Wu} \mathrm{JH}$. Tanshinone derivatives: a patent review (January 2006 - September 2012). Expert Opinion on Therapeutic Patents. 2013;23(1):19-29.

24. Zhang J, Huang M, Guan S, et al. A mechanistic study of the intestinal absorption of cryptotanshinone, the major active constituent of Salvia miltiorrhiza. Journal of Pharmacology and Experimental Therapeutics. 2006;317(3):1285-1294.

25. Guo ZJ, Zhang Y, Tang X, Li H, Sun QS. Pharmacokinetic interaction between tanshinones and polyphenolic extracts of Salvia miltiorrhiza Bunge after intravenous administration in rats. Biological and Pharmaceutical Bulletin. 2008;31(8):1469-1474.

26. Yang S, Zhang K, Lin X, et al. Pharmacokinetic comparisons of single herb extract of Fufang Danshen preparation with different combinations of its constituent herbs in rats. Journal of Pharmaceutical and Biomedical Analysis. 2012;67-68:77-85.

27. Xue M, Cui Y, Wang H, Luo Y, Zhang B, Zhou Z. Pharmacokinetics of cryptotanshinone and its metabolite in pigs. Acta Pharmaceutica Sinica. 1999;34(2):81-84.

28. Hao H, Wang G, Li P, Li J, Ding Z. Simultaneous quantification of cryptotanshinone and its active metabolite tanshinone IIA in plasma by liquid chromatography/tandem mass spectrometry (LC-MS/MS). Journal of Pharmaceutical and Biomedical Analysis. 2006;40(2): $382-388$.

29. Song M, Hang TJ, Zhang ZX, Du R, Chen J. Determination of cryptotanshinone and its metabolite in rat plasma by liquid chromatography-tandem mass spectrometry. Journal of Chromatography B: Analytical Technologies in the Biomedical and Life Sciences. 2005; 827(2):205-209.
30. Liu M, Wang Q, Liu F, et al. UDP-glucuronosyltransferase 1A compromises intracellular accumulation and anti-cancer effect of tanshinone IIA in human colon cancer cells. PLoS One. 2013;8(11):e79172.

31. Liu J, Zhu J, Du Z, Qin B. Preparation and pharmacokinetic evaluation of tanshinone IIA solid lipid nanoparticles. Drug Development and Industrial Pharmacy. 2005;31(6):551-556.

32. Zhang WL, Liu JP, Liu XX, Chen ZQ. Stealth tanshinone IIA-loaded solid lipid nanoparticles: effects of poloxamer 188 coating on in vitro phagocytosis and in vivo pharmacokinetics in rats. Yао хие хие bao = Acta Pharmaceutica Sinica. 2009;44(12):1421-1428.

33. Li Q, Wang Y, Feng N, Fan Z, Sun J, Nan Y. Novel polymeric nanoparticles containing tanshinone IIA for the treatment of hepatoma. Journal of Drug Targeting. 2008;16(10):725-732.

34. Hu L, Xing Q, Meng J, Shang C. Preparation and enhanced oral bioavailability of cryptotanshinone-loaded solid lipid nanoparticles. AAPS PharmSciTech. 2010;11(2):582-587.

35. Wang Y, Song D, Costanza F, et al. Targeted delivery of tanshinone IIA-conjugated mPEG-PLGA-PLL-cRGD nanoparticles to hepatocellular carcinoma. Journal of Biomedical Nanotechnology. 2014;10(11):3244-3252.

36. Fan Z, Li J, Dong C. Preparation and study on the inclusion complexes of two tanshinone compounds with $\beta$-cyclodextrin. Spectrochimica Acta Part A: Molecular and Biomolecular Spectroscopy. 2005;61(1-2):135-140.

37. Ma H, Fan Q, Yu J, Xin J, Zhang C. Anticancer activities of tanshinone microemulsion against hepatocellular carcinoma in vitro and in vivo. Molecular Medicine Reports. 2013;7(1):59-64.

38. Ma H, Fan Q, Yu J, Xin J, Zhang C. Novel microemulsion of tanshinone IIA, isolated from Salvia miltiorrhiza Bunge, exerts anticancer activity through inducing apoptosis in hepatoma cells. Am JChin Med. 2013;41(1):197-210.

39. Zhang J, LiY, Fang X, Zhou D, Wang Y, Chen M. TPGS-g-PLGA/Pluronic F68 mixed micelles for tanshinone IIA delivery in cancer therapy. International Journal of Pharmaceutics. 2014;476(1-2):185-198.

40. Liang WF, Li ZW, Ji Set al. Microbial glycosylation of tanshinone IIA by Cunninghamella elegans AS 3.2028. Royal Society of Chemistry Advances. 2015;5:63753-63756.

41. Li G, Shan C, Liu L, et al. Tanshinone IIA inhibits HIF-1alpha and VEGF expression in breast cancer cells via mTOR/p70S6K/RPS6/4EBP1 signaling pathway. PLoS One. 2015;10(2):e0117440.

42. Lin C, Wang L, Wang H, Yang L, Guo H, Wang X. Tanshinone IIA inhibits breast cancer stem cells growth in vitro and in vivo through attenuation of IL-6/STAT3/NF-kB signaling pathways. Journal of Cellular Biochemistry. 2013;114(9):2061-2070.

43. Chiu SC, Huang SY, Chen SP, Su CC, Chiu TL, Pang CY. Tanshinone IIA inhibits human prostate cancer cells growth by induction of endoplasmic reticulum stress in vitro and in vivo. Prostate Cancer and Prostatic Diseases. 2013;16(4):315-322.

44. Munagala R, Aqil F, Jeyabalan J, Gupta RC. Tanshinone IIA inhibits viral oncogene expression leading to apoptosis and inhibition of cervical cancer. Cancer Letters. 2015;356(2 Pt B):536-546.

45. Chen L, Wang HJ, Xie W, Yao Y, Zhang YS, Wang H. Cryptotanshinone inhibits lung tumorigenesis and induces apoptosis in cancer cells in vitro and in vivo. Molecular Medicine Reports. 2014;9(6):2447-2452.

46. Su CC, Lin YH. Tanshinone IIA down-regulates the protein expression of ErbB-2 and up-regulates TNF-alpha in colon cancer cells in vitro and in vivo. International Journal of Molecular Medicine. 2008;22(6):847-851.

47. Su CC. Tanshinone IIA potentiates the efficacy of 5-FU in Colo205 colon cancer cells in vivo through downregulation of P-gp and LC3-II. Experimental and Therapeutic Medicine. 2012;3(3):555-559.

48. Zhang Y, Won SH, Jiang C, et al. Tanshinones from Chinese medicinal herb Danshen (Salvia miltiorrhiza Bunge) suppress prostate cancer growth and androgen receptor signaling. Pharmaceutical Research. 2012;29(6):1595-1608.

49. Su CC, Chien SY, Kuo SJ, Chen YL, Cheng CY, Chen DR. Tanshinone IIA inhibits human breast cancer MDA-MB-231 cells by decreasing LC3-II, Erb-B2 and NF-kappaBp65. Molecular Medicine Reports. 2012;5(4):1019-1022. 
50. Shan YF, Shen X, Xie YK, et al. Inhibitory effects of tanshinone II-A on invasion and metastasis of human colon carcinoma cells. Acta Pharmacologica Sinica. 2009;30(11):1537-1542.

51. Yuxian X, Feng T, Ren L, Zhengcai L. Tanshinone II-A inhibits invasion and metastasis of human hepatocellular carcinoma cells in vitro and in vivo. Tumori. 2009;95(6):789-795.

52. Xiao J, Zhang G, Qiu P, et al. Tanshinone IIA increases the bystander effect of herpes simplex virus thymidine kinase/ganciclovir gene therapy via enhanced gap junctional intercellular communication. PLoS One. 2013;8(7):e67662.

53. Lu Q, Zhang P, Zhang X, Chen J. Experimental study of the anti-cancer mechanism of tanshinone IIA against human breast cancer. International Journal of Molecular Medicine. 2009;24(6):773-780.

54. Zhang X, Zhang P, Chen J, Lu Q. A study on the effect of tanshinone IIA against human breast cancer in vivo. Journal of Sichuan University. Medical Science Edition. 2010;41(1):67-72.

55. Yang L, Guo H, Dong L, Wang L, Liu C, Wang X. Tanshinone IIA inhibits the growth, attenuates the stemness and induces the apoptosis of human glioma stem cells. Oncology Reports. 2014;32(3): 1303-1311.

56. Chien SY, Kuo SJ, Chen YL, Chen DR, Cheng CY, Su CC. Tanshinone IIA inhibits human hepatocellular carcinoma J5 cell growth by increasing Bax and caspase 3 and decreasing CD31 expression in vivo. Molecular Medicine Reports. 2012;5(1):282-286.

57. Zhang Z, Gao J, Wang Y, et al. Tanshinone IIA triggers p53 responses and apoptosis by RNA polymerase II upon DNA minor groove binding. Biochemical Pharmacology. 2009;78(10):1316-1322.

58. Liu F, Yu G, Wang G, et al. An NQO1-initiated and p53-independent apoptotic pathway determines the anti-tumor effect of tanshinone IIA against non-small cell lung cancer. PLoS One. 2012;7(7): e42138.

59. Lee CY, Sher HF, Chen HW, et al. Anticancer effects of tanshinone I in human non-small cell lung cancer. Molecular Cancer Therapeutics. 2008;7(11):3527-3538.

60. He X, Zeng B, Liu H. Effect of tanshinone II A on acquired multi-drug resistance of S180'S tumor and expression of P-gp, LRP and TOPO II in mice. Journal of Traditional Chinese Medicine University of Hunan. 2010;30(7):16-18

61. Liu MZ, Huang YS, Xiao WQ. [No promoting effects of sodium tanshinone II-A sulfonate on growth and metastasis of Lewis carcinoma]. Zhongguo yao li xue bao =Acta Pharmacologica Sinica. 1991;12(6): 534-537. Chinese.

62. Wang WQ, Liu L, Sun HC, et al. Tanshinone IIA inhibits metastasis after palliative resection of hepatocellular carcinoma and prolongs survival in part via vascular normalization. Journal of Hematology and Oncology. 2012;5:69.

63. Tian HL, Yu T, Xu NN, et al. A novel compound modified from tanshinone inhibits tumor growth in vivo via activation of the intrinsic apoptotic pathway. Cancer Letters. 2010;297(1):18-30.

64. Guerram M, Jiang ZZ, Yousef BA, et al. The potential utility of acetyltanshinone IIA in the treatment of HER2-overexpressed breast cancer: induction of cancer cell death by targeting apoptotic and metabolic signaling pathways. Oncotarget. 2015;6(26):21865-21877.

65. Zhou LH, Hu Q, Sui H, et al. Tanshinone II-a inhibits angiogenesis through down regulation of COX-2 in human colorectal cancer. Asian Pacific Journal of Cancer Prevention: APJCP. 2012;13(9): 4453-4458.

66. Wang X, Wei Y, Yuan S, et al. Potential anticancer activity of tanshinone IIA against human breast cancer. International Journal of Cancer. Journal International du Cancer. 2005;116(5):799-807.

67. Chen J, Shi DY, Liu SL, Zhong L. Tanshinone IIA induces growth inhibition and apoptosis in gastric cancer in vitro and in vivo. Oncology Reports. 2012;27(2):523-528.

68. Zhou J, Xu XZ, Hu YR, Hu AR, Zhu CL, Gao GS. Cryptotanshinone induces inhibition of breast tumor growth by cytotoxic CD4+ T cells through the JAK2/STAT4/ perforin pathway. Asian Pacific Journal of Cancer Prevention: APJCP. 2014;15(6):2439-2445.
69. Park IJ, Yang WK, Nam SH, et al. Cryptotanshinone induces G1 cell cycle arrest and autophagic cell death by activating the AMP-activated protein kinase signal pathway in HepG2 hepatoma. Apoptosis: An International Journal on Programmed Cell Death. 2014;19(4): 615-628.

70. $\mathrm{Xu} \mathrm{D,} \mathrm{Lin} \mathrm{TH,} \mathrm{Li} \mathrm{S,} \mathrm{et} \mathrm{al.} \mathrm{Cryptotanshinone} \mathrm{suppresses} \mathrm{androgen}$ receptor-mediated growth in androgen dependent and castration resistant prostate cancer cells. Cancer Letters. 2012;316(1):11-22.

71. Lin TH, Lee SO, Niu Y, et al. Differential androgen deprivation therapies with anti-androgens casodex/bicalutamide or MDV3100/Enzalutamide versus anti-androgen receptor ASC-J9(R) lead to promotion versus suppression of prostate cancer metastasis. The Journal of Biological Chemistry. 2013;288(27):19359-19369.

72. Lee HJ, Jung DB, Sohn EJ, et al. Inhibition of hypoxia inducible factor alpha and astrocyte-elevated gene- 1 mediates cryptotanshinone exerted antitumor activity in hypoxic PC-3 cells. Evidence-Based Complementary and Alternative Medicine: eCAM. 2012;2012:390957.

73. Gong Y, Li Y, Lu Y, et al. Bioactive tanshinones in Salvia miltiorrhiza inhibit the growth of prostate cancer cells in vitro and in mice. International Journal of Cancer. 2011;129(5):1042-1052.

74. Li Y, Gong Y, Li L, Abdolmaleky HM, Zhou JR. Bioactive tanshinone I inhibits the growth of lung cancer in part via downregulation of Aurora A function. Molecular Carcinogenesis. 2013;52(7):535-543.

75. Nizamutdinova IT, Lee GW, Lee JS, et al. Tanshinone I suppresses growth and invasion of human breast cancer cells, MDA-MB-231, through regulation of adhesion molecules. Carcinogenesis. 2008;29(10): $1885-1892$.

76. Tung YT, Chen HL, Lee CY, et al. Active component of Danshen (Salvia miltiorrhiza Bunge), tanshinone I, attenuates lung tumorigenesis via inhibitions of VEGF, cyclin A, and cyclin B expressions. Evidence-Based Complementary and Alternative Medicine: eCAM. 2013;2013:319247.

77. Tsai SL, Suk FM, Wang CI, et al. Anti-tumor potential of 15, 16-dihydrotanshinone I against breast adenocarcinoma through inducing G1 arrest and apoptosis. Biochemical Pharmacology. 2007;74(11): 1575-1586.

78. Ye Y, Xu W, Zhong W, Li Y, Wang C. Combination treatment with dihydrotanshinone I and irradiation enhances apoptotic effects in human cervical cancer by HPV E6 down-regulation and caspases activation. Molecular and Cellular Biochemistry. 2012;363(1-2):191-202.

79. Chen CH, Liu DZ, Fang HW, Liang HJ, Yang TS, Lin SY. Evaluation of multi-target and single-target liposomal drugs for the treatment of gastric cancer. Bioscience, Biotechnology, and Biochemistry. 2008;72(6):1586-1594.

80. Wang C, Du X, Yang R, et al. The prevention and treatment effects of tanshinone IIA on oestrogen/androgen-induced benign prostatic hyperplasia in rats. The Journal of Steroid Biochemistry and Molecular Biology. 2015;145:28-37.

81. Niu XH, Hua HY, Guo WJ, et al. [Clinical efficiency of tanshinone II A-sulfonate in treatment of liver fibrosis of advanced schistosomiasis]. Zhongguo Xue Xi Chong Bing Fang Zhi Za Zhi. 2013;25(2): 137-140. Chinese.

82. Wang J, Lu W, Wang W, et al. Promising therapeutic effects of sodium tanshinone IIA sulfonate towards pulmonary arterial hypertension in patients. Journal of Thoracic Disease. 2013;5(2):169-172.

83. Therapeutic effect of sodium tanshinone IIA sulfonate in patients with coronary heart disease. A double blind study. Shanghai Cooperative Group for the Study of Tanshinone IIA. Journal of Traditional Chinese Medicine. 1984;4(1):20-24. Chinese.

84. Yang L, Zou XJ, Gao X, et al. Sodium tanshinone IIA sulfonate attenuates angiotensin II-induced collagen type I expression in cardiac fibroblasts in vitro. Experimental and Molecular Medicine. 2009;41(7):508-516.

85. Tan X, Yang Y, Cheng J, Li P, Inoue I, Zeng X. Unique action of sodium tanshinone II-A sulfonate (DS-201) on the Ca2+ dependent BKCa activation in mouse cerebral arterial smooth muscle cells. European Journal of Pharmacology. 2011;656(1-3):27-32. 
86. Chan SE, Lai HW, Su CC, et al. Effect of supplementation of tanshinone IIA and sodium tanshinone IIA sulfonate on the anticancer effect of epirubicin: an in vitro study. Evidence-Based Complementary and Alternative Medicine: eCAM. 2011;2011:841564.

87. Xu D, Lin TH, Zhang C, et al. The selective inhibitory effect of a synthetic tanshinone derivative on prostate cancer cells. The Prostate. 2012;72(7):803-816.

88. Xu Z, Wu L, Sun Y, et al. Tanshinone IIA pretreatment protects free flaps against hypoxic injury by upregulating stem cell-related biomarkers in epithelial skin cells. BMC Complementary and Alternative Medicine. 2014;14:331.

89. Xu Z, Zhang Z, Wu L, et al. Tanshinone IIA pretreatment renders free flaps against hypoxic injury through activating Wnt signaling and upregulating stem cell-related biomarkers. International Journal of Molecular Sciences. 2014;15(10):18117-18130.

90. Yang YM, Liu T. Complete remission of acute promyelocytic leukemia resisting all-trans retinoic acid of one case treated by tanshinone II A. Journal of Sichuan University. Medical Science Edition. 2006;37(6):965-967. Chinese.

91. Yang L, Gong YP, Yang YM, Luo S. A successful case of tanshinone II A treatment for relapsed acute promyelocytic leukemia after maintenance therapy of all-trans retinoic acid and arsenic trioxide. Journal of Sichuan University. Medical Science Edition. 2010;41(6): 1065-1067. Chinese.

92. Chen XL, Q. [Clinical observation on composite salviae dropping pill combined with FAM regimen in the treatment of gastric carcinoma]. Chinese Journal of Integrated Traditional and Western Medicine on Digestion. 2004;12:3. Chinese.

93. Chen X, Liang Q, Li X, Zhang Y, Li J, Liang Z. [Effect of composite salviae dropping pill combined with chemotherapy in patients with colorectal carcinoma]. Chinese Journal of Surgery of Integrated Traditional and Western Medicine. 2005;11:3. Chinese.

94. Liang Q, Chen X, Li X, et al. [Evaluate the effect of composite salviae dropping pill combined with PPF regimen chemotherapy in patients with advanced esophageal carcinoma]. The Practical Journal of Cancer. 2005;20:3. Chinese.
95. Chen X, Liang Q, Li X, et al. Effect of composite salviae dropping pill combined with chemotherapy in 41 cases with pancreatic carcinoma. Journal of Oncology. 2005;13(1):49-51. Chinese.

96. Liang Q, Chen X, Li X, et al. [Evaluate the clinical effect of composite salviae dropping pill combined with chemotherapy in patients with hepatocellular carcinoma]. Chinese Archives of Traditional Chinese Medicine. 2006;24:3. Chinese.

97. Liang Q, Zhang Y, Xie J, Li S, Luo H, Li X. [Clinical study on efficacy of compound Danshen droplet pill with chemotherapy in treating advanced non-small cell lung cancer]. Shanghai Journal of Chinese Medicine. 2007;41:3. Chinese.

98. Ji B, Wang S, Jing B. Study of composite salviae miltiorrhizae injection on acute leukemia. Modern Journal of Integrated Traditional Chinese and Western Medicine. 2004;13(22):2958-2959. Chinese.

99. Jiang D, Li Q, Ding H, Huang J, Wang X, Shi L. Clinical research on prevention of recurrence by trans-umbilical-portal vein perfusion of Fufang Danshen in patients with hepatocellular carcinoma. The Practical Journal of Cancer. 2007;22(4):39-41. Chinese.

100. Li Y, Zhu J, Li Y, Wang Y, Zhang W. The efficiencies of hepatic artery infusion with the liquid compound of Radix Salvia Miltiorrhizae and segmental hepatic artery chemoembolization in HCC. Chinese Imaging Journal of Integrated Traditional and Western Medicine. 2006;4(5):352-355. Chinese.

101. Liu AH, Lin YH, Yang M, Sun JH, Guo H, Guo DA. High-performance liquid chromatographic determination of tanshinones in the roots of Salvia miltiorrhiza and related traditional Chinese medicinal preparations. Journal of Pharmacy and Pharmaceutical Sciences: A Publication of the Canadian Society for Pharmaceutical Sciences, Societe canadienne des sciences pharmaceutiques. 2006;9(1):1-9.
Botanics: Targets and Therapy

\section{Publish your work in this journal}

Botanics: Targets and Therapy is an international, peer-reviewed, open access journal focusing on the discovery and development of active compounds based upon or found naturally occurring in the plant kingdom that may have therapeutic potential in any disease state. The manuscript management system is completely online and includes a very

\section{Dovepress}

quick and fair peer-review system. Visit http://www.dovepress.com/ testimonials.php to read real quotes from published authors. 